\title{
Board of Commissioners in Corporate Governance, Firm Performance, and Ownership Structure
}

\author{
Cynthia A. Utama*, Sidharta Utama** \\ * Department of Management, Faculty of Economic and Business, Universitas Indonesia, Kampus UI Depok 16424, Indonesia \\ *** Department of Accounting, Faculty of Economic and Business, Universitas Indonesia, Kampus UI Depok 16424, Indonesia
}

\begin{tabular}{|c|c|}
\hline ARTICLE INFO & A B S T R A C T \\
\hline $\begin{array}{l}\text { JEL: G32, G34, O16 } \\
\text { Keywords: } \\
\text { board size, } \\
\text { board of commissioners, } \\
\text { corporate governance, } \\
\text { firm performance, } \\
\text { ownership structure, } \\
\text { cash-flow rights, } \\
\text { control rigths } \\
\text { Kata Kunci: } \\
\text { ukuran dewan, } \\
\text { dewan komisaris, } \\
\text { tata kelola, } \\
\text { kinerja perusahaan, } \\
\text { struktur kepemilikan, } \\
\text { hak arus kas, } \\
\text { hak kendali. }\end{array}$ & $\begin{array}{l}\text { The purpose of this study is to investigate: firstly, the two-way causality } \\
\text { between firms performance and the size of BOC; secondly, the non- } \\
\text { linear effect of board size on the firms' performance; thirdly, the direct } \\
\text { and moderating effects of the ownership structure on the influence } \\
\text { of firm performance on board size. Using the ROA as a measure of } \\
\text { firm performance, we find that there is a simultaneous relationship } \\
\text { between firm performance and the size of BOC: the size of the board } \\
\text { has an inverted U-shaped effect on firm performance while firms } \\
\text { performance has a negative influence on board size. We find that the } \\
\text { size of the board of commissioners increases firm performance up } \\
\text { to a certain level, but a very large board reduces firm performance. } \\
\text { We find marginal evidence that ownership structure has a moderating } \\
\text { effect on the impact of firm performance on board size. We document } \\
\text { that the negative effect of performance on board size dissipates as } \\
\text { ownership right increases. The negative effect of performance on } \\
\text { board size marginally strengthens. Thus, our study contributes to the } \\
\text { literature by finding that the negative influence of firm performance } \\
\text { and board primarily occurs on firms that are subject to high incentive } \\
\text { expropriation by controlling shareholders. }\end{array}$ \\
\hline
\end{tabular}

\section{SARI PATI}

Tujuan dari studi ini adalah untuk menginvestigasi: pertama, hubungan dua arah antara kinerja perusahaan dan ukuran BOC; kedua, pengaruh non-linear dari ukuran dewan terhadap kinerja perusahaan; ketiga, pengaruhlangsung dan tidaklangsung dari struktur kepemilikan terhadap efek kinerja perusahaan pada ukuran dewan. Dengan menggunakan ROA sebagai ukuran kinerja perusahaan, hasil studi menunjukkan terdapat hubungan timbal-balik antara kinerja perusahaan dan ukuran BOC; ukuran dewan memiliki pengaruh berbentuk U-terbalik terhadap kinerja perusahaan sementara kinerja perusahaan pengaruh negatif pada ukuran dewan. Hasil studi menunjukkan bahwa ukuran dewan komisaris meningkatkan kinerja perusahaan sampai pada tingkatan tertentu, namun ukuran dewan yang terlalu besar menurunkan kinerja perusahaan. Selanjutnya, struktur kepemilikan memiliki pengaruh tidak 
langsung namun tidak terlalu kuat terhadap efek kinerja perusahaan pada ukuran dewan. Selain itu, kinerja perusahan tidak berpengaruh terhadap ukuran dewan seiring peningkatan struktur kepemilikan. Di sisi lain, jika perbedaan antara kendali dan hak kepemilikan meningkat, efek negatif dari kinerja perusahaan terhadap ukuran dewan menguat secara marginal. Dengan demikian, kontribusi studi ini adalah pengaruh negatif kinerja perusahaan terhadap ukuran dewan cenderung terjadi pada perusahaan dengan pemegang saham mayoritas yang memiliki insentif tinggi untuk melakukan ekspropriasi.

(C) 2019 IRJBS, All rights reserved.

\section{INTRODUCTION}

The board of directors, as a supervisory body that provides strategic guidance, is the center of the internal mechanism of corporate governance practices (Brown and Caylor 2006). There are two types of board structures, i.e. the single board and the dual board. Firms in Indonesia are mandated to employ a dual board structure: The Board Of Commissioners (BOC) and the Board Of Directors (BOD). The BOD determines the short term and long term strategic decisions and manages the company, while the BOC oversees and advises the BOD on the running of the company. The BOC's role is very important for minimizing the agency problem so shareholders' wealth maximization can be attained. Under a single board, a number of studies have investigated the influence of the BOD's effectiveness on their firm performance (Hermalin and Weishbach 1991; Bhagat and Black 2001; Yermack 1996; Eisenberg et al. 1998). In Indonesia, extant studies related to the BOC's effectiveness include Wardhani (2006) who investigates the BOC's effectiveness as one determinant of the probability of financial distress and Hermawan (2009) who investigates the BOC's effectiveness as one determinant of the information content of earnings.

Previous studies that consider a non-linear and simultaneous relationship between a board size and its firm performance are very rare. For example, Coles et al. (2008) and Arosa et al. (2013) find the relationship between a firm performance and board size is an inverted " $U$-shaped" form, meaning that the board's effectiveness is optimal if its size is not too large or too small. Further, Belkhir (2008) affirms that board size can improve firm performance and at the same time, firm performance determines board size. However, the extant literature that investigates both the non-linear relationship between firm performance and board size and the endogeneity relationship between firm performance and board size is nonexistent.

Munisi et al. (2014) find that board size and ownership concentration have a substitution effect and thus a negative relationship between ownership concentration and board size. A higher ownership concentration reduces the demand for independent monitoring by a large board because shareholders with the larger holdings will take more responsibility for monitoring the managers. However, Munisi et al. (2014) do not consider the possible moderating effect of the ownership concentration on the relationship between board size and firm performance. We posit that the substitution effect weakens the negative effect of firm performance and board size.

Further, while a higher ownership concentration increases the incentive of large shareholders to monitor managers, it may also increase the incentive of large shareholders to expropriate the firm's wealth if there is a divergence between the control rights and ownership rights/shares (Claessens et 
al., 2002b). So far, no study has examined both the impact of the risk of expropriation on board size and the relationship between performance and size of the board. We argue that better oversight, as represented by a larger board, is needed to reduce the risk of expropriation and thus we suggest that the divergence between the control and cash-flow rights may have direct and indirect effects on board size.

Based on the above explanations, the aims of this study are to investigate: 1) The simultaneous relationship between board size and firm performance, 2) whether the impact of board size on firm performance is non-linear, 3) whether different measures of ownership structure have different impacts on board size, and 4) whether different measures of ownership structure have moderating effects on the influence of firm performance on board size. Thus our study examines the direct effect of ownership structure on board size as well as its indirect effect on board size through its impact on the relationship between firm performance and board size. We employ two dimensions of the firm's ownership structure: The share ownership/cash-flow rights of the largest shareholder and the divergence between the control rights and cash-flow rights of the largest shareholder.

The contributions of the study are as follow. First, to our knowledge, previous studies investigate board structures in countries that follow a single board system, thus the measurement of those board structures is generally related to the independent directors (outside directors) or duality CEOs (i.e., one person holds the function of being both the CEO and chairman) (Klein 1998; Denis and Sarin 1999; Hermalin and Weisbach 1988; Bhagat and Black 2001). Under the dual board structure, such as in Indonesia, the primary task of the BOC is to oversee the BOD, which manages the company. Its members consist only of non-executives. Thus, it is an empirical question to examine the simultaneous effect between board size and performance under this different setting. Second, no study has examined the non-linear relation between board size and performance under the condition of simultaneous relationship between board size and firm performance. Coles et al (2008) find the non-linear relation; however, their study ignores the simultaneous relation between board size and performance. Thus, our study contributes to the literature by examining this non-linear relation under the setting of simultaneous relationship between board size and firm performance.

Third, previous studies that investigated the direct influence of ownership concentration on board size are still rare (For example, Munisi et al. 2014). They also do not consider the impact of the divergence between cash-flow rights and control rights (Claessens et al. 2002a,b) on board size. The use of cash-flow rights and control rights enables us to investigate the alignment effect and the entrenchment effect of ownership concentration on board size. Last but not least, to our knowledge, this study is the first one that investigate the moderating effect of different measures of ownership concentration on the relationship between board size and firm performance.

To pursue our objectives, this paper proceeds as follows: In the next section, we elaborate on our literature review and hypotheses development. In the third section, we elaborate the research design. The results, implications, and main conclusions of the study are discussed in the final sections.

\section{Literature Review And Hypotheses Development} In this section, we provides a brief overview of a board structure and an independent commissioner in Indonesia, followed by the hypotheses development.

\section{Board Structure and Independent Commissioner in Indonesia}

As mentioned earlier, there are two types of board structures, i.e. a single board structure that is commonly used by Anglo-Saxon countries and a 
dual board structure that is commonly used by continental European countries. Under a single board structure, the executive directors and nonexecutive directors are not separated. Under the dual board structure, the management board is responsible for managing the company and providing its general direction, while the supervisory board provides oversight of the management board and may approve the major business decisions.

Firms in Indonesia follow the dual board structure, i.e., the supervisory body (i.e., the BOC) and management (i.e., the BOD). The primary task of the $\mathrm{BOC}$ is to oversee the BOD, which manages the company. Its members consist of non-executives, i.e., commissioners only. The Law of the Republic of Indonesia No. 40 of 2007 concerning a limited liability company states that:

"BOD is the company organ which is fully reliable upon the company for the interests and objectives of the company, as well as represents the company, both in and out of court, in accordance with the provisions of the Article Of Association (AOA). Whereas, the BOC are defined as the company's organ assigned to general and/or specific conduct supervision in accordance with the $A O A$ and giving advice to the $B O D$. The $B O D$ and $B O C$ are elected and dismissed by a General Meeting of the Shareholders (GMS). The GMS holds supreme power and all the authorities that are not submitted to the BOD and BOC.

Article 108(5) of the Corporation Act (UndangUndang no. 402007 tentang Perseroan Terbatas) and Bapepam-LK Rule IX.J.1 on the AOA for public companies, issued by the capital market regulator in Indonesia, requires public companies to have at least two members on the BOC. Note, before 2011, the capital market regulator was Badan Pengawas Pasar Modal dan Lembaga Keuangan (BapepamLK) while since 2011, it is Otoritas Jasa Keuangan (OJK) or the Financial Service Authority.

In addition, the listing rule mandates public companies to have independent commissioners, with the minimum proportion of independent commisioners to be $30 \%$. According to BapepamLK rule IX.I.5, the criteria for an independent commisioner are: 1) Comes from outside the public company where he or she takes the position of an independent commissioner, 2) does not have direct or indirect share ownership in the public company, 3) does not have an affiliated relationship with the commisioner, directors, and major shareholders, 4) does not have a direct or indirect business relationship with the public company.

The requirement for the size of the $\mathrm{BOC}$ is quite low, i.e., at least two commissioners. As a result, many listed companies have only two or three commissioners. The following section elaborates how board size and performance are affecting each other and how ownership structure influences the relationship.

\section{Theoretical Background: Ownership Concentration and Agency Problem}

Concentrated ownership can be characterized as a corporate governance mechanism to reduce the agency problem of managers. The larger the fraction of shares is to the total outstanding shares owned by the largest shareholder, the higher are the incentives to monitor the manager because the benefits will outweigh the costs incurred (Shleifer and Vishny 1986; Mishra 2011; Munisi et al. 2014). However, concentrated ownership may also raise the agency problem between the controlling shareholders and minority shareholders. The controlling shareholders may intervene in the firm's decision making process for their own interests, even if this conduct comes at the expense of other stakeholders (Shleifer and Vishny 1986; Conheady et al. 2015).

Claessens et al. (2002a) and Claessens et al. (2002b) suggest that the effect of concentrated ownership on a firm value depends on the cash flow rights and control rights of the controlling/largest shareholders. Cash-flow rights measure the relative ownership or investment of the controlling shareholders in the 
firm, while the control rights represent the relative control the controlling shareholders have over the firm. If controlling shareholders directly own the company, then their control rights and cashflow rights are the same. However, if controlling shareholders indirectly own the company through layers of ownership, then their control rights can be higher than their cash-flow rights. The indirect ownership of a company through a layer(s) of ownership is called a pyramid ownership structure. An example of the measurement of cash-flow and control rights is as follows: Mr. A owns 60\% of Company X and Company X owns 50\% of Company $\mathrm{Y}$, which is a publicly listed company. In this case, the cash-flow rights of Mr. A in company Y are 30\% (i.e., $60 \%$ x 50\%) while his control right is 50\% (i.e., the lower of the chains of ownership). Thus, to measure the cash-flow and control rights, one has to obtain data and trace the percentage ownership through layers of ownership until the ultimate owner is identified.

Claessens et al. (2002b) suggests that higher cashflow rights reduce the incentive of controlling shareholders to expropriate their firm's wealth and this should result in a higher firm value/better firm performance. The reason is that if controlling shareholders divert the firm's wealth for their own private benefit then their high stake in the firm will be jeopardized as well. Therefore, controlling shareholders with the higher cash flow rights are associated with an increase of the alignment effect between the controlling shareholders and the noncontrolling shareholders and any agency problems that could arise between controlling shareholders and non-controlling shareholders will decrease.

Claessens et al. (2002b) further proposes that higher control rights, and at the same time lower cash-flow rights, increases the incentive for controlling shareholders to expropriate the firms' wealth for their own private benefit and reduce the company's value. Higher control rights enable controlling shareholders to more easily arrange transactions that expropriate their firm's wealth while the lower cash-flow rights mean that they bear a smaller share of the losses resulting from such transactions. Thus, controlling shareholders with a higher divergence between their control and cash-flow rights are associated with the increase of the entrenchment effect between controlling shareholders and non-controlling shareholders, and agency problems between controlling and non-controlling shareholders will be exacerbated.

Thus, in summary, cash-flow rights and the divergence between control and cash flow rights reflect the positive effect and negative effect of a firm's ownership concentration on its performance.

Hypotheses Development: The Impact of Board Size on Firm Performance

Dalton et al. (1999) finds that board size has a positive impact on firm performance because a bigger sized board can improves its advisory function to the CEO. This finding is also corroborated by Puspita and Lukviarman (2007) who find a positive relationship between board size and bank performance. Proponents of this view argue that a firm performance is better with a larger board, because a larger board provides a greater depth of knowledge, a better quality of strategic decision making, better monitoring and performs its advisory role better. A larger sized board also means increased human capital, with better specific knowledge about the business and the board's information. (Van den Berghe and Levrau, 2004; Arosa et al., 2013).

On the contrary, other studies show that board size has a negative relationship with firm performance. Jensen (1993) argues that a bigger sized board is less efficient due to the complexities of the agency problem among the members of the board. Increasing the size of the board causes difficulties in communications, coordination, and the decisionmaking process and thus decreases the board's effectiveness. Finally, the lower effectiveness of the board decreases firm performance. Therefore, 
a limit on the size of the board has the purpose of increasing the board's effectiveness (Goodstein et al. 1994; Yermack 1996).

Further, Garcia-Olalla and Garcia-Ramos (2010), Arosa et al. (2013) corroborate that the impact of board size on firm performance is a trade-off between benefits and costs. Coles et al. (2008), Arosa et al. (2013) show that more complex firms need greater and better monitoring and advisory functions and therefore require larger boards. Further they note that the relationship between a firm performance and its board size is an invested "U-shaped" form, meaning that the board's effectiveness is optimal if its size is not too small or not too large.

In general, the empirical studies that have investigated the influence of board size on firm performance employ the total number of executive and non-executive directors on the board as the measure of board size (e.g. Yermack 1996; Dalton et al. 1999; Conyon and Peck 1998; de Andress et al. 2005; O'Connell and Cramer 2010). To our knowledge no study has investigated the influence of the size of the BOC has on performance. Under the dual board structure, executives cannot sit on the BOC, and this should enable the BOC to perform its oversight role more independently than that of a BOD under the single board structure. Therefore, we expect that the size of the $\mathrm{BOC}$ also has an influence on its firm performance. Further, based on previous studies (Jensen, 1993; Garcia-Olalla and GarciaRamos 2010; Arosa et al. 2013), we expect that the relationship between the size of the $\mathrm{BOC}$ and firm performance is non-linear, i.e., the relationship between firm performance and board size is an "inverted U-shape" because a very large board has difficulties in communicating, coordinating, and in their decision making process, and thus decreases the board's effectiveness (Jensen, 1993) while a very small board lowers the depth of knowledge, the oversight and the advisory quality of the board. Thus, we posit the first hypothesis as follows:
H1: There is an inverted-U-shaped relationship between board size and firm performance

Hypotheses Development: The Impact of Firm Performance on Board Size

A number of studies state and find that a firm performance has influence on its board size. For example, a badly performing firm may experience a high turnover in its directors, since the existing members of the board are replaced by new members (Hermalin and Weisbach 1988). This finding is also supported by Gilson (1990), Yermack (1996), and Peng et al. (2015): their results show that the turnover on boards tends to increase after firms experience poor performance/results. Gilson (1990) also finds that firms tend to increase their board size when they undergo financial distress. A larger board is expected to improve the monitoring and advisory functions of underperforming firms so the firm's results improve. Further, Yermack (1996) shows that firms which perform badly force the firm to increase the number of outsiders on its board's structure. The outsiders are expected to increase the independency of the board and to increase the firm performance. Based on these arguments, the second hypothesis is stated as follows:

\section{H2: Firm performance has a negative influence on board size.}

Hypothesis Development: The direct and indirect effects of ownership concentration on board size

We employ three measures of ownership concentration: The direct share ownership of the largest shareholder, the cash-flow rights of the largest shareholder and the divergence between the control and the cash flow rights of the largest shareholder (i.e., cash-flow leverage). Cash-flow rights measures the direct and indirect ownership of the ultimate shareholder. On the other hand, the direct share of ownership only directly measures the ownership of a shareholder. Indonesia has a high 
prevalence of pyramid ownership structures that enables shareholders to directly and indirectly own a listed company through several chains of layers of ownership. Thus, the share of ownership will have measurement errors if the company has a pyramid structure ownership. On the other hand, calculating the cash-flow rights requires the availability of ownership information throughout all the chains and layers of ownership. The unavailability of this information reduces the number of eligible companies, and this reduces the power of the test. For this reason, we use both variables to measure the share ownership of the largest shareholder.

Based on the explanation in the theoretical background, we propose that higher ownership/ cash-flow rights of the largest shareholder reduces the demand for a large board, because shareholders with a large ownership will have more incentive and take more responsibility for monitoring their managers and for maximizing the value of their companies. This is in line with Guest (2008), Chen and Al-Najjar (2012), and Munisi et al. (2014), who show that there is a substitution effect between the alternative governance mechanisms, that is, a higher concentrated ownership reduces the need for the greater monitoring and advisory role of a bigger board. Moreover, a smaller sized board is needed to reduce the free rider and organizational costs related with having a larger board (Munisi et al. 2014). In other words, high ownership/cash-flow rights substitute for a large board size in providing the oversight function. Thus, we expect that a higher percentage of the ownership/cash-flow rights by the largest shareholder will decrease the size of the BOC. Based on above argument, we formulate the following hypothesis:

H3: The share ownership/cash flow rights of the largest shareholder have a negative impact on board size.

A higher divergence between the control rights and the cash-flow rights creates a higher incentive for the controlling shareholders to expropriate the company's assets for their own benefit (Claessens et al. 2002a, 2002b). Under this condition, a larger sized board is required to mitigate this agency problem. Strong oversight by a large board is expected to reduce the risk of expropriation and improve performance. Based on above arguments, we state the following hypothesis:

H4: The divergence between control rights and cash flow-rights has a positive impact on board size.

We posit that the effect of a concentration of ownership on the size of the board may also be indirect, i.e., by moderating the effect of firm performance on board size. As explained in the argument for Hypothesis 2, a large board is needed to provide sufficient oversight and direction to the managers of poorly performing firms. However, under the condition of a large ownership stake, a large sized board is not necessary for improving firm performance since the controlling shareholders will have the incentive to improve the performance of their firm. As a result, the negative relationship between a firm performance and its board size is not observed for companies whose controlling shareholders have a large ownership of shares/ cash-flow rights. On the other hand, the negative relationship should be strong for companies with a low ownership of shares/cash-flow rights since under this condition, the shareholders' monitoring is weak and thus a large sized board is needed to improve a poor performing firm. Therefore, we state the following hypothesis:

H5: The negative effect of firm performance on board size is weakened with a greater level of ownership/cash-flow rights.

Firms with a high divergence between their control and cash flow rights have a high risk of expropriation by their controlling shareholders. Under this condition, the negative effect of firm performance on its board size should be stronger for the following reason. A large sized board is necessary to perform 
its monitoring role in a poorly performing company and assuring that the expropriation is not sustained. On the other hand, good performing firms imply that the risk of expropriation has not yet materialized; and thus, firms do not need large boards. Thus, performance and board size have a negative relationship only when the ownership structure increases the risk of expropriation.

Therefore, we state the following hypothesis:

H6: The negative effect of firm performance on board size is strengthened for firms with a greater divergence between their control and cash flow rights.

\section{RESEARCH DESIGN}

\section{Variable Measurement}

We use the Return On Assets (ROA) to measure a firm performance. This measurement indicates the deployment of a firm's assets and their returns (Ross, Westerfield, and Jordan 2009). Many previous studies used this measurement to investigate its relationship with the board's governance (Puspita and Lukviarman 2007) and size (Yermack 1996). ROA is the ratio of net income per total assets, and stated as a percentage. However, accounting numbers are subject to manipulation (Cornett et al. 2008; O'Connell and Cramer 2010) and because of the conservatism principle, bad news is revealed more quickly by the accounting numbers than good news (O'Connell and Cramer 2010). Hence, we also utilize the Price to Book Value of equity (PBV) as a proxy of Tobin's $Q$ to measure the expected performance of the firm in the future. A higher PBV signifies a higher expected risk adjusted profit in the future. The drawback of the PBV is that it assumes that stock prices reflect the intrinsic value of the stock with no bias, while in reality that may not be the case. In addition, the PBV also suffers from conservatism practices, i.e. the book value of equity will become more biased downwards as the financial statements become more conservative. The number of members of the BOC measures board size for each firm in time period $t$.
Ownership right is measured by two proxies: The percentage of the direct ownership of the largest shareholders (LRGSHR) as disclosed in the annual reports of firms; and secondly, the Cash Flow Rights (CFR). The incentive to expropriate is measured by the divergence between the cash flow rights and control rights (Cash-flow leverage or CFL). As mentioned in the previous section, LRGSHR contains a measurement error while the low number of observations for CFR and CFL reduces the power of the test.

We employ debt level, the proportion of independent commissioners, institutional ownership and ownership concentration as control variables in the regression models with performance as the dependent variable, and employ firm size and firm age as control variables in the regression models with board size as the dependent variable. We use debt ratio (i.e., total debt per total assets) to measure the relative use of debt in financing. To measure firm size, we deploy the log of the market capitalization. This study follows the measurement of a firm age by Cheng et al. (2008), i.e. the period from the listing date of the firm on the Indonesian stock exchange until the last period of financial reporting. The proportion of independent commissioners is computed as the number of independent commissioners divided by the total number of board members at time period $t$.

Institutional ownership is measured as a dummy variable, taking a value of one if the percentage of the institutional ownership exceeds $20 \%$, otherwise zero. The use of a binary variable to measure the level of ownership has been widely used by previous studies (e.g., Croci et al, 2012; Morck et al, 1998; La Porta, 1999; Claessens et al, 2000). We use a $20 \%$ cut off point in line with previous studies, such as by La Porta (1999) and Claessens et al. (2000). La Porta et al. (1999) categorized five types of ultimate owners, i.e. : (1) A family or an individual, (2) the State, (3) a widely held financial institution such as a bank or an insurance company, (4) a widely held corporation, or (5) miscellaneous, such as a 
cooperative, a voting trust, or a group with no single controlling investor. They argue that the largest ultimate owner must have at least $20 \%$ to exercise control over the company. Further, the capital market law (UU RI Number 8 year 1995) states that someone is categorized as a major shareholder if he/she directly or indirectly holds at least $20 \%$ of the company's voting rights. Hence, we use $20 \%$ as the threshold since it is commonly accepted that by owning more than $20 \%$, the shareholder will have a significant influence on the company's affairs.

\section{Sample and Data Collection}

Data on the cash-flow rights and control rights are obtained from Diyanti et al. (2010), which only used manufacturing firms. Therefore, the initial samples of the study are manufacturing firms listed on the Indonesian stock exchange in 2007 and 2008. The manufacturing sectors are composed of certain industries: Food and Beverages, Tobacco, Textile Mills, Apparel and other Textiles, Lumber and Mills, Paper and Allied, Chemical and Allied, Adhesives, Plastics and Glass, Cement, Metal and Allied, Fabricated Metal, Stone, Clay, Glass and Concrete Products, Cables, Electronic and Office Equipment, Automotive and Allied Products, Photographic Equipment, Pharmaceuticals and Consumer Goods. Data on direct ownership of the largest shareholder are provided by Melati et al. (2010). Data from financial reports, such as their ROA, board composition and other data are gathered from the Indonesian Capital Market Directory (ICMD) and the reference center for the capital market.

The global financial crisis took place in year 2008 and it caused the Indonesia Stock Market Index to drop by more than $50 \%$ in year 2008. Its impact on the economic growth of Indonesia, however, was not significant since the GDP of Indonesia still managed to growth $4 \%$ in year 2008. The effect of the crisis on variables employed in our study primarily is on the performance variable, especially on PBV, whose values in year 2008 was much lower than those in year 2007. The impact of the crisis on ROA of our samples was not significant since as mentioned above, its influence on the Indonesian economy was not severe. The global financial crisis might have affected the results of our study, especially those involving PBV as a measure of performance; therefore, the results should be interpreted with caution.

There are 149 and 151 listed manufacturing firms in 2008 and 2007 respectively. The total number of observations based on the availability of the largest shareholders' ownership are 238 firm-years, and the total observations based on the availability of the cash-flow rights and control rights are 105 firmyears. The results of the sample selection process are shown in Table 1.

Table 1. Summary of the Sample's Selection Procedure

\begin{tabular}{lr}
\hline \multicolumn{1}{c}{ Data } & N \\
\hline Listed manufacturing firms in 2008 & 149 \\
$\quad$ Firms with missing or incomplete data & $(25)$ \\
$\quad$ Delisted firms & $(3)$ \\
$\quad$ Number of firms in 2008 & 121 \\
Listed manufacturing firms in 2007 & 151 \\
$\quad$ Firms with missing or incomplete data & $(18)$ \\
$\quad$ Delisted firms & $(4)$ \\
$\quad$ Number of firms in 2007 & 129 \\
Total observations & 250 \\
Total observations according to ownership structure's data: & \\
a. Total observations according to data of large shareholders' ownership & 238 \\
b. Total observations according to data of cash-flow rights and control rights & 105 \\
\hline
\end{tabular}




\section{Empirical Model}

We employ Two Stage Least Square (2SLS) to investigate simultaneity between firm performance and board size.

Since we have two measures of a firm performance (ROA and PBV) and two measures of ownership concentration (direct ownership by the largest shareholder and cash-flow rights/divergence between the cash-flow and control rights), to test Hypotheses 1 to 4 we have to employ two simultaneous regression models (Equations 1 and 2). To test the hypotheses with moderating variables (Hypotheses 5 and 6), we use another two regression models (Equations 3 and 4). The models are as follows:

\section{Models 1 (ROA) and 3 (PBV)}

PERFORM $_{i t}=\alpha_{0}+\alpha_{1}$ BOC $_{i t}+\alpha_{2}$ BOC $_{i t}^{2}+\alpha_{3} I_{I N D E P_{i t}}$ $+\alpha_{4}$ LARGESHR $_{i t}+\alpha_{5}$ INST $_{i t}+\alpha_{6}$ DEBT $_{i t}+\varepsilon_{i t} \ldots$ (1a)

BOC $_{i t}=\beta_{0}+\beta_{1}$ PERFORM $_{i t}+\beta_{2}$ LARGESHR $_{i t}+$ $\beta_{3} \operatorname{lnFSIZE} E_{i t}+\beta_{4} \ln A G E_{i t}+\mu_{i t}$

where PERFORM is either the Return On Assets (ROA) or the Price to Book Value of equity (PBV).

Models 2 (ROA) and 4 (PBV)

PERFORM $_{i t}=\alpha_{0}+\alpha_{1}$ BOC $_{i t}+\alpha_{2}$ BOC $_{i t}^{2}+\alpha_{3} I N D E P_{i t}$ $+\alpha_{4}$ CFR $_{\text {it }}+\alpha_{5} \mathrm{CFL}_{\mathrm{it}}+\alpha_{6} \mathrm{INST}_{\mathrm{it}}+\alpha_{7} \mathrm{DEBT}_{i t}+\varepsilon_{\text {it }}(2 \mathrm{a})$

BOC $_{i t}=\beta_{0}+\beta_{1}$ PERFORM $_{i t}+\beta_{2}$ CFR $_{i t}+\beta_{3}$ CFL $_{i t}+$ $\beta_{4} \ln F S I Z E_{i t}+\beta_{5} \ln A G E_{i t}+\mu_{i t}$

where:

$$
\begin{array}{ll}
\alpha_{0}, \beta_{0} & =\text { intercept } \\
\mathrm{i} & =\text { company indicator, } \\
\mathrm{t} & =\text { time } \mathrm{t}, \\
\mathrm{ROA} & =\text { return on assets, } \\
\mathrm{PBV} & =\text { price to book value, } \\
\text { BOC } & =\text { size of the board of commissioners, } \\
\text { BOC }^{2} & =\text { square of the BOC, } \\
\text { LARGESHR } & =\text { percentage of large shareholders, } \\
\text { CFR } & =\text { cash flow rights, }
\end{array}
$$

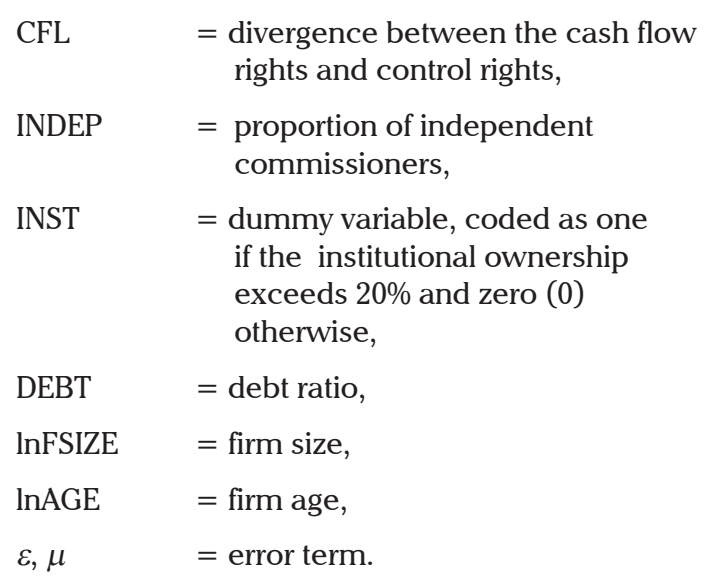

For Hypothesis 1, to have a quadratic curve with a maximum point in Equations (1a) and (2a), the expectations for $\alpha_{1}$ are positive and $\alpha_{2}$ are negative. For Hypotheses 2 and 3, in Equations (1b) and (2b) $\beta_{1}$ and $\beta_{2}$ are negative respectively. For Hypothesis $4, \beta_{3}$ in Equation (2b) is positive.

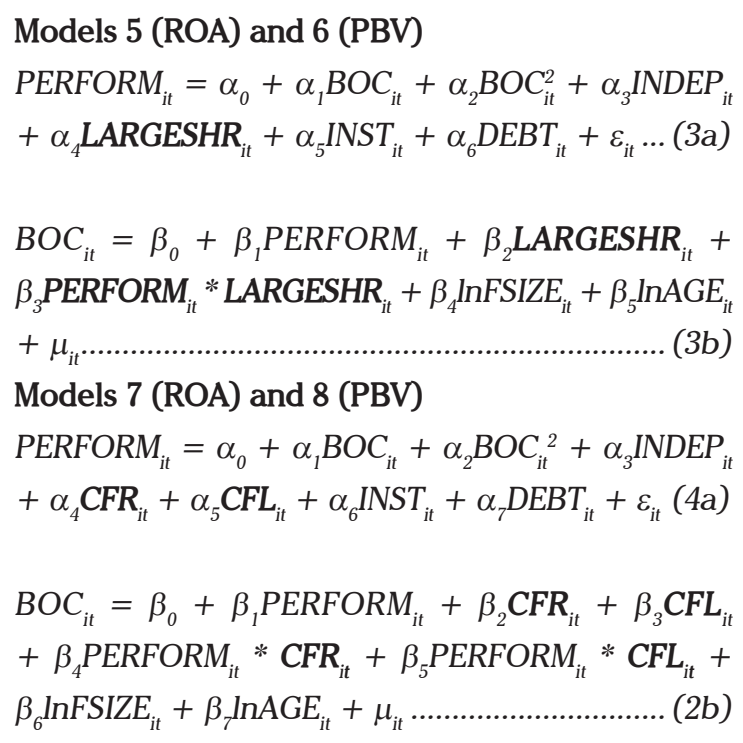

For Hypothesis 5, in Equation (3b) $\beta_{3}$ is positive and in Equation (4b) $\beta_{4}$ is positive. For Hypothesis $6, \beta_{5}$ in Equation (4b) is negative.

An explanation of the effect of the control variables on the dependent variables is as follows.

1. Dependent variables: Firm performance

a. Ownership concentration Many previous studies show that large 
shareholders have a positive impact on their firm performance because concentrated ownership allows them to exert their voting rights to motivate and discipline the managers. They can also use their knowledge and resources to enrich the resource base of the firm (Carney and Gedajlovic, 2001; Sing, 2015). If we use the cash flow rights and control rights as a measurement of ownership concentration, we expect that cash flow rights have a positive influence on firm performance and cash flow leverage has a negative influence on firm performance.

b. Proportion of Independent Commissioners The existence of independent outside directors/commissioners is to mitigate the conflict between managers and shareholders. Independent directors/commissioners provide the following benefits to companies, i.e.: 1) Their capabilities can provide value added to the company (Fama and Jensen 1983; Eliyanora 2008); 2) even though independent commisioners (outsiders) have less information related to the company than the proper (insider) directors, they perform their monitoring function objectively, whereas the insiders tend to pursue their own aims and may jeopardise the shareholders' wealth (Raheja 2005). Thus, the higher proportion of independent commissioners is expected to have positive impacts on firm performance.

c. Institutional ownership

Leng (2004) finds that firm performance, measured by ROE, will be higher for firms with a higher concentrated ownership by institutional investors. The empirical study conducted by Lehman and Weigand (2000) finds that a highly concentrated ownership by financial institutions' investors will increase firm performances, as measured by the ROA. Thus, the existence of the financial institutions should improve the corporate governance and performance of the firms. Further, Cornet et al. (2007) finds that institutional ownership has a positive impact on the operating cash flows' returns. But, the positive impact is only found if the institutional investors do not have a business relationship with the firm (pressure-insensitive). On the contrary, they do not find a relationship between institutional investors and operating cash flows' returns if the institutional investors have an existing or potential relationship with the firm (pressure-sensitive). The reason is institutional investors have vested interests to protect their business relationship with the firm. Nevertheless, Demsetz and Lehn (1985), and Duggal and Millar (1999) note that institutional ownership does not impact a firm performance if it is treated as an endogenous variable. Using companies that conduct takeovers, Duggal and Millar (1999) who employ Two-Stage Least Squares (2SLS) find that the institutional ownership of the acquirors is significantly affected by the firm size, its insider ownership, and the firm's presence in the S\&P 500 index, but there is no relationship between institutional ownership and firm performance. If they employ an OLS regression, they find that the institutional ownership in bidding firms enhances the efficiency in the market for corporate control.

\section{d. Debt level}

Debt as an external financing can be used to mitigate the agency problem between managers and shareholders, because: 1) Debt will force managers to pay interest on a timely basis (control hypothesis); 2) if managers fail to pay the interest and principal of the debt then the creditors will enforce the firm's bankruptcy and consequently the manages may lose their jobs (thread hypothesis) (Jensen and Meckling, 1976). Therefore, debt can mitigate the agency problem between managers and 
shareholders and improve firm performance. But, according to the static trade-off theory, if the bankruptcy risk outweighs the benefit of the debt (i.e. tax shields and reducing the agency problems) then debt financing may decrease firm performance. Therefore, we assert that debt has an influence (i.e. positive or negative) on firm performance.

2. Dependent variable: Board size

a. Firm size

Firm size has a positive impact on board size because a bigger sized firm requires higher levels of monitoring and advice; consequently a larger board is needed (Coles et al., 2008). This argument is supported by Linck et al.'s (2008) finding that a larger sized board is required for larger firms, which have higher levels of complexity than smaller firms. Even though the monitoring costs are higher, the benefits of the more effective monitoring outweigh the cost.

b. Firm age

Firm age is also found to have a positive impact on board size because older firms are more complex than younger firms; so a larger board is required to supervise such firms (Linck et al., 2008). This study follows the measurement of a firm age by Cheng et al. (2008), i.e. the period from the listing date of the firm on the Indonesian stock exchange until the last period's financial report.

\section{EMPIRICAL RESULTS}

\section{Descriptive Statistics}

The descriptive statistics in Table 2 show that the average ROA is $4.44 \%$, indicating that the performance of our sample firms is relatively low. Further, there is wide variation in their ROA, i.e. between $-90.37 \%$ and $147.82 \%$. The average PBV is 1.92 , meaning that investors are willing to pay almost double for one unit of equity because they expect the firms to earn more than the cost of their equity. The average board size is four commissioners, showing that in general the boards are relatively small. Nevertheless, the variation is quite wide, i.e. between 2 and 11 commissioners.

The average ownership percentage of the largest shareholders (49.9\%) is quite high for them to

Table 2. Descriptive Statistics of the Variables Employed in the Study $(n=238)$

\begin{tabular}{lcccccc}
\hline & Minimum & Maximum & Mean & Std. Deviation & \multicolumn{2}{c}{ Kurtosis } \\
\cline { 2 - 7 } ROA & Statistic & Statistic & Statistic & Statistic & Statistic & Std. Error \\
\cline { 2 - 6 } PBV & -90.370 & 147.820 & 4.444 & 15.705 & 38.684 & 0.314 \\
BOC & 0.010 & 20.830 & 1.923 & 2.937 & 23.359 & 0.314 \\
INDEP & 2.000 & 11.000 & 4.248 & 1.861 & 1.428 & 0.314 \\
LRGSHR & 0.000 & 1.000 & 0.324 & 0.186 & 2.068 & 0.314 \\
INST & 0.000 & 0.980 & 0.499 & 0.226 & -0.810 & 0.314 \\
DEBT & 0.000 & 1.000 & 0.420 & 0.495 & -1.910 & 0.314 \\
LOGSIZE & 0.050 & 0.990 & 0.513 & 0.208 & -0.662 & 0.314 \\
LOGAGE & 8.440 & 18.520 & 12.900 & 1.905 & 0.210 & 0.314 \\
CFR & 0.690 & 3.430 & 2.637 & 0.418 & 3.716 & 0.314 \\
CFL & 0.060 & 0.930 & 0.452 & 0.249 & -1.166 & 0.467 \\
\hline
\end{tabular}

Note: $\mathrm{ROA}=$ Return On Assets, $\mathrm{PBV}=$ (Stock) Price to Book Value of equity per share, BOC = size of BOC, INDEP $=$ proportion of independent commissioners, LRGSHR = percentage ownership of the largest shareholders, INST $=$ dummy variable, coded as 1 for institutional ownership greater than $20 \%$ and zero otherwise, DEBT = debt over total assets, LOGSIZE $=\log$ (firm) size, LOGAGE $=\log$ (firm age), CFR $=$ Cash-Flow Rights, CFL = Cash-Flow Rights - Control Rights. 
Table 3. Pearson Correlation Analysis

\begin{tabular}{|c|c|c|c|c|c|c|c|c|c|}
\hline & ROA & PBV & $\mathrm{BOC}$ & $\mathrm{BOC}^{2}$ & INDEP & LRGSHR & INST & DEBT & LNSIZE \\
\hline \multirow[t]{2}{*}{ PBV } & $0.128^{* *}$ & & & & & & & & \\
\hline & 0.024 & & & & & & & & \\
\hline \multirow[t]{2}{*}{ BOC } & 0.036 & $0.113^{*}$ & & & & & & & \\
\hline & 0.580 & 0.080 & & & & & & & \\
\hline \multirow[t]{2}{*}{ BOC2 } & 0.032 & $0.110^{*}$ & $0.977^{* * *}$ & & & & & & \\
\hline & 0.618 & 0.090 & 0.000 & & & & & & \\
\hline \multirow[t]{2}{*}{ INDEP } & 0.011 & -0.067 & 0.034 & 0.057 & & & & & \\
\hline & 0.433 & 0.152 & 0.302 & 0.192 & & & & & \\
\hline \multirow[t]{2}{*}{ LRGSHR } & 0.060 & $0.240^{* * * *}$ & 0.048 & 0.044 & -0.090 & & & & \\
\hline & 0.179 & 0.000 & 0.231 & 0.250 & 0.083 & & & & \\
\hline \multirow[t]{2}{*}{ INST } & 0.057 & -0.045 & 0.079 & 0.068 & 0.050 & $-0.170^{* * * *}$ & & & \\
\hline & 0.189 & 0.245 & 0.113 & 0.147 & 0.221 & 0.004 & & & \\
\hline \multirow[t]{2}{*}{ DEBT } & $-0.219^{* * *}$ & $0.176^{* * *}$ & $0.136^{* *}$ & $0.117^{* *}$ & -0.098 & -0.077 & 0.104 & & \\
\hline & 0.000 & 0.003 & 0.018 & 0.036 & 0.067 & 0.118 & 0.054 & & \\
\hline \multirow[t]{2}{*}{ LOGSIZE } & $0.218^{* * *}$ & $0.294^{* * * *}$ & $0.520^{* * * *}$ & $0.498^{* * * *}$ & 0.051 & $0.208^{* * * *}$ & 0.077 & -0.052 & \\
\hline & 0.000 & 0.000 & 0.000 & 0.000 & 0.218 & 0.001 & 0.119 & 0.210 & \\
\hline \multirow[t]{2}{*}{ LOGAGE } & $0.239^{* * *}$ & 0.087 & $0.199^{* * *}$ & $0.157^{* * * *}$ & $-0.171^{* * * *}$ & 0.055 & 0.066 & 0.084 & $0.205^{* * *}$ \\
\hline & 0.000 & 0.090 & 0.001 & 0.008 & 0.004 & 0.199 & 0.156 & 0.097 & 0.001 \\
\hline
\end{tabular}

Note: ROA= Return On Assets, PBV = (Stock) Price to Book Value of equity per share, BOC $=$ size of BOC, INDEP = proportion of independent commissioners, LRGSHR = percentage ownership of the largest shareholders, INST $=$ dummy variable, coded as 1 for institutional ownership greater than $20 \%$ and zero otherwise, DEBT $=$ debt over total assets, LOGSIZE $=\log ($ firm $)$ size, LOGAGE $=\log ($ firm age).

$*, * *, * * *$ indicate significance at the $0.1,0.05$ and 0.01 levels, respectively. The given p-value is provided below the correlation coefficient. The given p-value for all variables already divided by 2 (two) because the hypotheses tests are onetailed test except for BOC.

intervene in their firms' decision making. The average cash-flow rights and control rights of the largest shareholder are about $45 \%$ and $55 \%$ respectively and thus the average divergence between the control and cash-flow rights is $10 \%$. Thus, by using a pyramid ownership scheme, on average the large shareholders are able to increase their control rights by $10 \%$.

The descriptive statistics also show that the average proportion of independent commissioners is $32.4 \%$, which is only slightly above the minimum $30 \%$ requirement. Many companies have a lower proportion of independent commissioners than the requirement, indicating that the requirements are not being fully enforced.

\section{Analysis of the Correlation among the Variables}

Table 3 presents the correlation coefficients among the variables. Only debt has a significant negative correlation with the ROA $(\rho=-0.219)$ at a significance level of $1 \%$. Other variables, i.e. board size, proportion of independent commissioners, and ownership structure (i.e., the percentage of large shareholders and institutional owners) do not have a significant correlation with the ROA. On the contrary with the results of the ROA, debt has a positive relationship with the $\operatorname{PBV}(\rho=0.176)$ at a significance level of $1 \%$.

The relationship between debt and firm performance depends on the measures of a firm performance: 1) If the proxy of a firm performance is its ROA, then the relationship between firm performance and debt is negative, supporting the static tradeoff theory; 2) if the proxy of a firm performance is its PBV, then the relationship between firm performance and debt is positive, supporting Jensen and Meckling's (1976) theory.

Further, the percentage ownership of the largest shareholders has a positive relationship with the 
Table 4. Regression Results of Simultaneous Relation between Board size and ROA

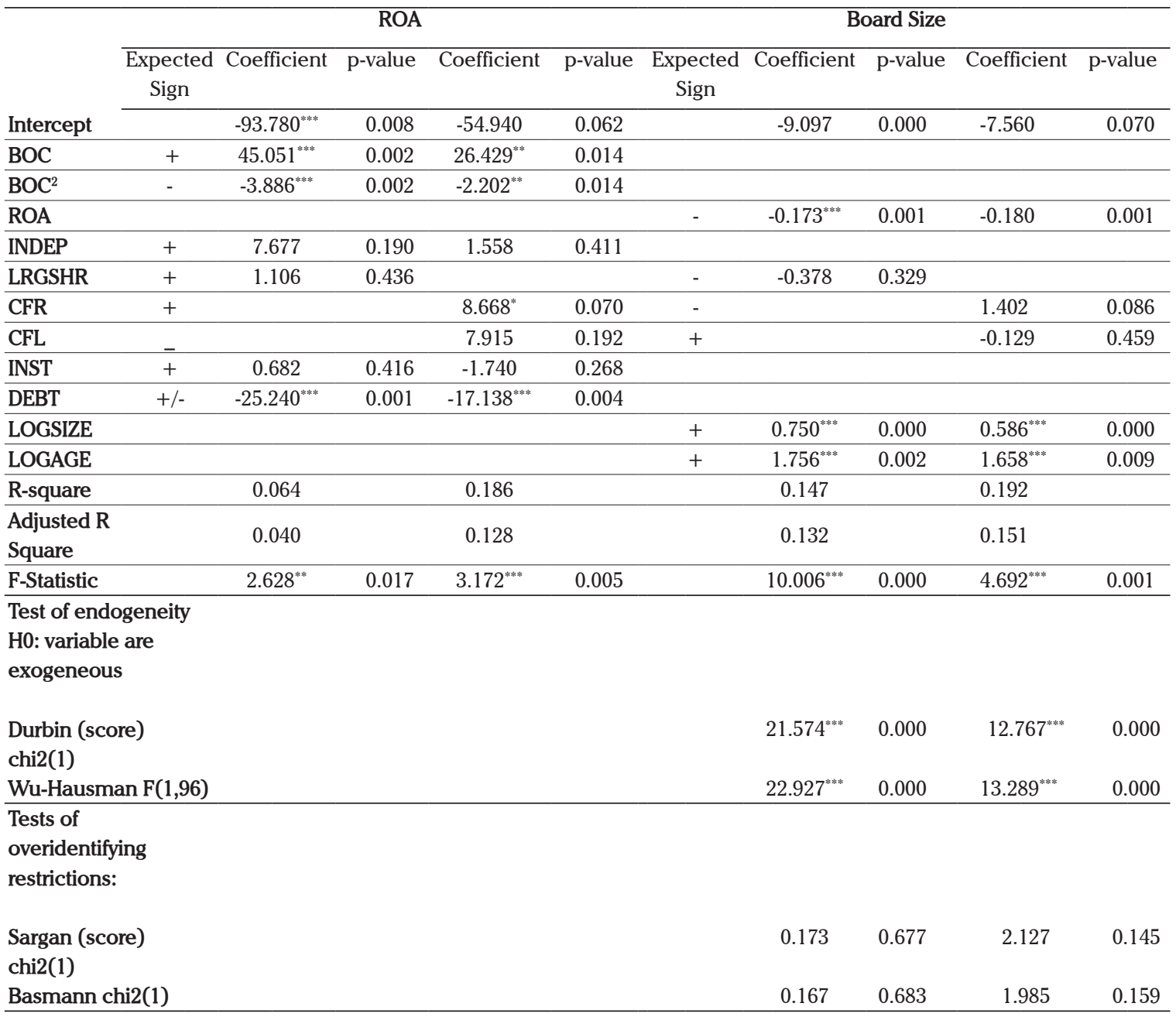

Note: $\mathrm{ROA}=$ Return On Assets, $\mathrm{PBV}=($ Stock$)$ Price to Book Value of equity per share, $\mathrm{BOC}=$ size of $\mathrm{BOC}$, INDEP = proportion of independent commissioners, LRGSHR = percentage ownership of the largest shareholders, CFR = Cash-Flow Rights, CFL $=$ Cash-Flow Rights - Control Rights, INST = dummy variable, coded as 1 for institutional ownership greater than $20 \%$ and zero otherwise, DEBT $=$ debt over total assets, LOGSIZE $=\log ($ firm $)$ size, LOGAGE $=\log$ (firm age).

*significant at 10 percent level; **significant at 5 percent level; ***significant at 1 percent level

$\operatorname{PBV}(\rho=0.240)$ at a significance level of $1 \%$. Finally, in accordance with expectations, the size of the board has a positive relationship with firm size $(\rho$ $=0.498)$ and firm age $(\rho=0.157)$ consecutively at a significance level of $1 \%$.

\section{Regression Results and Analysis}

Simultaneous Relationship between Board Size and Firm Performance

Table 4 (Table 5) provides the results of the twostage least squares regression between board size and the ROA (PBV). We test the endogeneity of board size and firm performance. The results accepts the alternate hypothesis of the existence of endogeneity of the variables (The Chi-square(1) in both tables have p-value lower than $1 \%$ ). Thus, the use of simultaneous relations between board size and firm performance is warranted.

We employ the Sargan test to examine the validity of instruments. In Table 4, the Sargan tests in 2SLS fail to reject the null hypothesis of validity of instruments ( $p$-values $=0.677$ and 0.156 for the first and the second regression respectively), indicating our instruments are valid. However, in Table 5, the results of Sargan tests reject the null hypothesis of validity of instruments $(p$-values $=0.036$ and 0.001 
for the first and the second regression respectively). Thus, to test our hypotheses, we only use the results of Table 4 that employs ROA as a measure of performance.

Based on the results, we find that there is a simultaneous relationship between a firm performance (i.e, ROA) and its board size, thus the first and second hypotheses are supported. First, the result supports that there is an inverted-U shaped relationship between the size of a firm's board and the firm performance. Hence, firm performance is higher with larger boards because larger boards provide a greater depth of knowledge, better quality strategic decisions, and play a better advisory role. Larger boards also improve the human capital factor, with better specific knowledge about the business and information from the board . (Van den Berghe and Levrau, 2004; Arosa et al., 2013). However, very large boards cause difficulties in communication, coordination, and the decision making process and thus decrease the effectiveness of the board and consequently, firm performance decreases (Jensen, 1993). Based on the 2SLS results, holding the other variables constant, we can calculate the number of commissioners that maximize the ROA and the result is 5.8 (in practice 6 ) commissioners. The number is greater than the average number of commissioners in the sample firms, suggesting that on average the number of commissioners in our samples is too small.

Second, firm performance has a significant negative influence on its board size. This result corroborates previous findings showing that firms tend to increase the size of their board when they undergo financial distress. Larger boards are expected to improve the monitoring and advisory functions so the result is better performance by the firm (Gilson, 1990). Other studies find that a firm's poor performance will force the firm to increase the number of outsiders in their board's structure. The outsiders are expected to increase the independency of the board and increase firm performance (Yermack, 1996). In the context of Indonesia, the result indicates that for poorly performing firms, oversight and strategic guidance by the BOC can be enhanced by having a larger BOC.

Direct Effect of Ownership Concentration on Board Size

The results with regard to the impact of ownership concentration on a board size do not support Hypothesis 3 in Table 4. Both the proportions of ownership by the largest shareholder (LRGSHR) and the cash-flow rights (CFR) do not have a significant negative impact on board size. This finding does not support previous studies that show the existence of a greater concentration of ownership will reduce the demand for increased monitoring by boards, as represented by their size, because the larger shareholders will take more responsibility for monitoring their firm's managers (Shleifer and Vishny 1986; Mishra 2011; Munisi et al. 2014). Thus, the results indicate that the existence of concentrated ownership does not have a direct influence on the size of a board.

Tables 4 shows that the coefficients for CFL are not significant, thus Hypothesis 4 is not supported. The results show that in our sample firms, board size is not employed to increase monitoring to reduce the risk of expropriation by the controlling shareholders. The insignificant results for the effect of ownership concentration on a board size may be due to the following plausible reasons: The results indicate that ownership concentration does not directly substitute for board size as a mechanism to oversee the management board. Klapper and Love (2004) find that firm-level corporate governance mechanisms have a stronger positive impact on performance in countries with weak legal environments. Given that the legal environment in Indonesia is relatively weak (LaPorta et al., 1998; Berkowitz et al., 2003), a strong governance mechanism (i.e., high cash-flow rights and at the same time a large sized board) is necessary to compensate for the weak legal efficacy in Indonesia. As a result, the direct substitute relationship between ownership concentration and board size may disappear. Further, under a weak 
Table 5. Regression Results of Simultaneous Relation between Board size and PBV

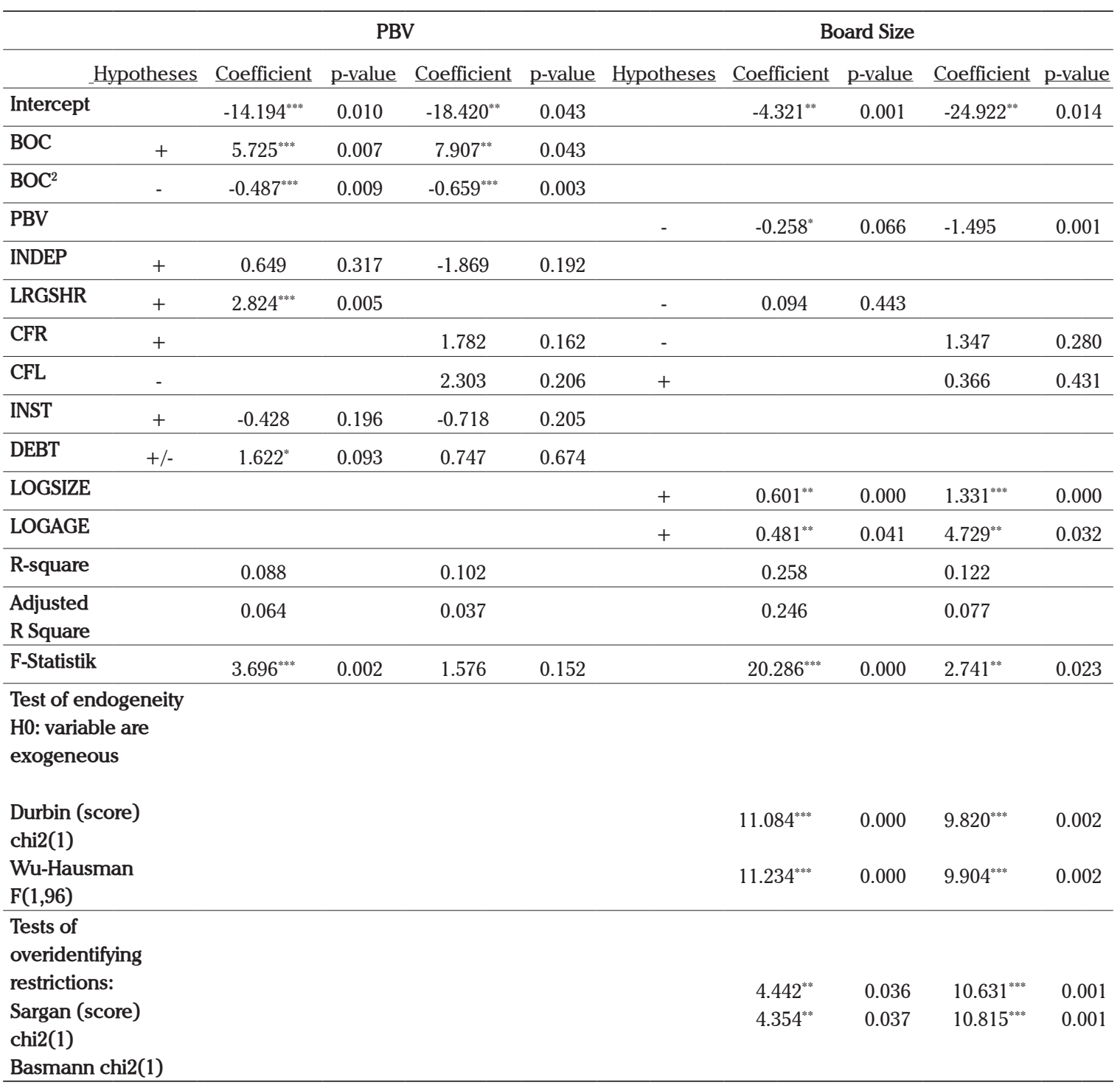

Note: $\mathrm{ROA}=$ Return On Assets, $\mathrm{PBV}=($ Stock$)$ Price to Book Value of equity per share, BOC = size of BOC, INDEP = proportion of independent commissioners, LRGSHR = percentage ownership of the largest shareholders, CFR $=$ Cash-Flow Rights, CFL = Cash-Flow Rights - Control Rights, INST = dummy variable, coded as 1 for institutional ownership greater than $20 \%$ and zero otherwise, DEBT $=$ debt over total assets, LOGSIZE $=\log ($ firm) size, LOGAGE $=\log ($ firm age).

*significant at 10 percent level; **significant at 5 percent level; ***significant at 1 percent level

legal environment, the likelihood of the controlling shareholders being penalized for expropriating the wealth of the non-controlling shareholders is low; as a result, the controlling shareholders may not see the need to have a larger board to increase the monitoring. An alternative explanation for the insignificant results is that measurement error in the LRGSHR or the low power of the tests of CFR and CFL causes the tests to fail to find the hypothesized relationship.
The results for the control variables are as follows: Related to the ownership's structure, we find that large shareholders do not have an impact on ROA. Further, this study shows that the cash flow rights have a positive impact on the ROA but any divergence of these cash flow rights and control rights does not have a significant impact ROA. Thus, cash flow rights may align the vested interests of the majority of the shareholders, including the minority shareholders (the alignment effect), and improve firm performance. 
Debt financing has a negative impact on the ROA. This result supports the static trade-off theory, stating that if the bankruptcy risk outweighs the benefit of the debt (i.e. tax shields and reducing the agency problems) then debt financing may decrease firm performance. This finding supports previous studies (Chaganti and Damanpour 1991; Lowenstein 1991; and Charfeddine and Elmarzougoui 2010), which find little evidence that institutional ownership is related with performance.

Finally, we can show that board size is positively affected by firm size and firm age. This finding supports the argument that larger sized and older firms usually are much more complex, so a larger board is needed to supervise such firms. (Linck et al. 2008; Coles et al. 2008).

Table 6. Regression Results of Simultaneous Relation between Board size and ROA with ROA and Ownership Structure as Interaction Variables

\begin{tabular}{|c|c|c|c|c|c|c|c|c|c|c|}
\hline & \multicolumn{4}{|c|}{ ROA } & \multicolumn{6}{|c|}{ Board Size } \\
\hline & Hypotheses & Coefficient & $\mathrm{p}$-value & Coefficient & $\mathrm{p}$-value & Hypotheses & Coefficient & $\mathrm{p}$-value & Coefficient & $\mathrm{p}$-value \\
\hline Intercept & & $-88.407^{* * * *}$ & 0.009 & -66.920 & 0.023 & & 2.703 & 0.693 & -0.450 & 0.901 \\
\hline $\mathrm{BOC}$ & + & $42.176^{\text {*at }}$ & 0.002 & $31.181^{\text {**** }}$ & 0.005 & & & & & \\
\hline $\mathrm{BOC}^{2}$ & - & $-3.673^{* * * *}$ & 0.002 & -2.163 & & & & & & \\
\hline ROA & & & & & & - & $-0.897^{* *}$ & 0.047 & $-0.319^{*}$ & 0.090 \\
\hline INDEP & + & 7.218 & 0.198 & 1.789 & 0.410 & & & & & \\
\hline LRGSHR & + & 1.241 & 0.621 & & & - & $-8.555^{*}$ & 0.050 & & \\
\hline CFR & + & & & 7.925 & 0.112 & - & & & -1.707 & 0.190 \\
\hline CFL & - & & & 9.785 & 0.162 & + & & & -1.107 & 0.304 \\
\hline INST & + & 0.792 & 0.399 & -2.159 & 0.245 & & & & & \\
\hline DEBT & $+/-$ & $-24.837^{* * *}$ & 0.001 & $-17.225^{* * *}$ & 0.009 & & & & & \\
\hline LOGSIZE & & & & & & + & 0.567 & 0.012 & 0.427 & 0.000 \\
\hline LOGAGE & & & & & & + & -0.058 & 0.481 & 0.193 & 0.435 \\
\hline ROALRGSHR & & & & & & + & $1.345^{*}$ & 0.050 & & \\
\hline ROACFR & & & & & & + & & & 0.397 & 0.114 \\
\hline ROACFL & & & & & & - & & & 0.313 & 0.297 \\
\hline R-square & & 0.064 & & 0.176 & & & 0.033 & & 0.163 & \\
\hline $\begin{array}{l}\text { Adjusted R } \\
\text { Square }\end{array}$ & & 0.040 & & 0.117 & & & 0.0122 & & 0.103 & \\
\hline F-Statistik & & $2.626^{* *}$ & 0.018 & $2.965^{* * *}$ & 0.007 & & 1.581 & 0.166 & $2.699^{* *}$ & 0.013 \\
\hline \multicolumn{11}{|c|}{$\begin{array}{l}\text { Test of endogeneity } \\
\text { H0: variable are } \\
\text { exogeneous }\end{array}$} \\
\hline $\begin{array}{l}\text { Durbin (scor } \\
\text { Wu-Hausma }\end{array}$ & $\begin{array}{l}\text { e) chi2(1) } \\
\text { n } F(1,96)\end{array}$ & & & & & & $\begin{array}{l}19.332^{* * * *} \\
20.334^{* * * *}\end{array}$ & $\begin{array}{l}0.000 \\
0.000\end{array}$ & $\begin{array}{l}24.426^{* * * *} \\
29.102^{* * * *}\end{array}$ & $\begin{array}{l}0.000 \\
0.000 \\
\end{array}$ \\
\hline \multicolumn{11}{|c|}{$\begin{array}{l}\text { Tests of overidentifying } \\
\text { restrictions: }\end{array}$} \\
\hline $\begin{array}{l}\text { Sargan (scor } \\
\text { Basmann ch }\end{array}$ & $\begin{array}{l}\text { e) chi2(1) } \\
\text { i2(1) }\end{array}$ & & & & & & $\begin{array}{r}76.005^{* * *} \\
107.443^{* * *} \\
\end{array}$ & $\begin{array}{l}0.000 \\
0.000 \\
\end{array}$ & $\begin{array}{l}19.723^{* * * *} \\
21.753^{* * * *}\end{array}$ & $\begin{array}{l}0.000 \\
0.000 \\
\end{array}$ \\
\hline
\end{tabular}

Note: $\mathrm{ROA}=$ Return On Assets, $\mathrm{PBV}=($ Stock$)$ Price to Book Value of equity per share, $\mathrm{BOC}=$ size of BOC, INDEP $=$ proportion of independent commissioners, LRGSHR = percentage ownership of the largest shareholders, CFR = Cash-Flow Rights, CFL $=$ Cash-Flow Rights - Control Rights, INST $=$ dummy variable, coded as 1 for institutional ownership greater than $20 \%$ and zero otherwise, DEBT $=$ debt over total assets, LOGSIZE $=\log ($ firm $)$ size, LOGAGE $=\log ($ firm age $)$.

*significant at 10 percent level; **significant at 5 percent level; ***significant at 1 percent level 
Table 7. Regression Results of Simultaneous Relation between Board size and PBV with PBV and Ownership Structure as Interaction Variables

\begin{tabular}{|c|c|c|c|c|c|c|c|c|c|c|}
\hline & \multicolumn{4}{|c|}{ PBV } & \multicolumn{6}{|c|}{ Board Size } \\
\hline & Hypotheses & $\underline{\text { Coefficient }}$ & p-value & $\underline{\text { Coefficient }}$ & $\mathrm{p}$-value & Hypotheses & Coefficient & p-value & $\underline{\text { Coefficient }}$ & $\mathrm{p}$-value \\
\hline Intercept & & $-5.584^{* * *}$ & 0.200 & 27.334 & 0.507 & & $-16.095^{* * *}$ & 0.002 & -10.614 & 0.305 \\
\hline BOC & + & 1.984 & 0.143 & -19.438 & 0.176 & & & & & \\
\hline $\mathrm{BOC}^{2}$ & - & -0.161 & 0.160 & 1.580 & 0.179 & & & & & \\
\hline PBV & & & & & & - & $7.178^{* * * *}$ & 0.001 & $-7.094^{* *}$ & 0.039 \\
\hline INDEP & + & -0.087 & 0.469 & -4.169 & 0.275 & & & & & \\
\hline LRGSHR & + & $3.040^{* * *}$ & 0.001 & & & - & 16.574 & 0.002 & & \\
\hline CFR & + & & & $42.967^{* *}$ & 0.041 & - & & & -4.622 & 0.316 \\
\hline CFL & - & & & 14.309 & 0.143 & + & & & $17.848^{*}$ & 0.096 \\
\hline INST & + & -0.254 & 0.265 & $6.939^{*}$ & 0.096 & & & & & \\
\hline DEBT & $+/-$ & $2.268^{* *}$ & 0.022 & 0.993 & 0.858 & & & & & \\
\hline LOGSIZE & & & & & & + & $0.321^{*}$ & 0.081 & $1.462^{* * * *}$ & 0.001 \\
\hline LOGAGE & & & & & & + & $2.167^{* * *}$ & 0.025 & 0.434 & 0.450 \\
\hline PBVLRGSHR & & & & & & + & -10.358 & 0.001 & & \\
\hline PBVCFR & & & & & & + & & & $8.051 * *$ & 0.045 \\
\hline PBVCFL & & & & & & - & & & -10.821 & 0.119 \\
\hline R-square & & 0.100 & & 0.047 & & & 0.069 & & 0.114 & \\
\hline $\begin{array}{l}\text { Adjusted R } \\
\text { Square }\end{array}$ & & 0.077 & & -0.022 & & & 0.049 & & 0.050 & \\
\hline F-Statistik & & $4.294^{* * *}$ & 0.000 & 0.678 & 0.690 & & $3.425^{* * * *}$ & 0.005 & $1.784^{*}$ & 0.099 \\
\hline $\begin{array}{l}\text { Test of endog } \\
\text { H0: variable } \\
\text { exogeneous }\end{array}$ & $\begin{array}{l}\text { eneity } \\
\text { re }\end{array}$ & & & & & & & & & \\
\hline $\begin{array}{l}\text { Durbin (scor } \\
\text { Wu-Hausmar }\end{array}$ & $\begin{array}{l}\text { chi2(1) } \\
F(1,96)\end{array}$ & & & & & & $\begin{array}{l}1.351 \\
1.313\end{array}$ & $\begin{array}{l}0.245 \\
0.253\end{array}$ & $\begin{array}{l}22.679^{* * * *} \\
26.447^{* * *}\end{array}$ & $\begin{array}{l}0.000 \\
0.000\end{array}$ \\
\hline $\begin{array}{l}\text { Tests of overi } \\
\text { restrictions: } \\
\text { Sargan (scor } \\
\text { Basmann chi }\end{array}$ & $\begin{array}{l}\text { lentifying } \\
\text { chi2(1) } \\
\text { (1) }\end{array}$ & & & & & & $\begin{array}{l}200.69^{* * *} \\
1231.8^{* * *}\end{array}$ & $\begin{array}{l}0.000 \\
0.000 \\
\end{array}$ & $\begin{array}{l}22.796^{* * *} \\
26.068^{* * *}\end{array}$ & $\begin{array}{l}0.000 \\
0.000\end{array}$ \\
\hline
\end{tabular}

Note: $\mathrm{ROA}=$ Return On Assets, $\mathrm{PBV}=($ Stock$)$ Price to Book Value of equity per share, $\mathrm{BOC}=$ size of BOC, INDEP $=$ proportion of independent commissioners, LRGSHR = percentage ownership of the largest shareholders, CFR = Cash-Flow Rights, CFL $=$ Cash-Flow Rights - Control Rights, INST = dummy variable, coded as 1 for institutional ownership greater than $20 \%$ and zero otherwise, DEBT $=$ debt over total assets, LOGSIZE $=\log ($ firm $)$ size, LOGAGE $=\log ($ firm age $)$.

*significant at 10 percent level; **significant at 5 percent level; ***significant at 1 percent level

The Moderating Effect of Ownership Structure on the Influence of the Firm Performance on Board Size

Table 6 provides the results of the regression with the interaction between the ROA and ownership concentration while Table 7 provides the results of the regression with the interaction between the PBV and ownership concentration. When we test for endogeneity of board size and firm performance. The result accepts the alternate hypothesis of endogeneity of both variables, with the exception when performance measure is PBV and ownership structure in large shareholder (LRGSHR). On the other hand, Sargan tests in 2SLS reject the null hypothesis of validity of instruments in both tables, indicating that our instruments are not valid. In conclusion the tests indicate that board size and firm performance are endogenous 
variables; however, the Sargan tests indicate that the instrument variables are not valid.

To overcome the issue of instrumental variables, based on the argument of Bun and Harrison (2014) and Bushman et al. (2004), we choose to use OLS to test the effect of the interaction of firm performance and ownership structure on board size. We follow the argument of Bun and Harrison (2014) as follow: "The endogeneity bias is reduced for the OLS estimator when the endogenous regressor is interacted with an exogenous covariate. The result implies that for testing on the presence of endogenous interactions one does not necessarily have to resort to IV techniques. Given the difficulties associated with finding valid instru- ments, our results suggest that the researcher may produce more reliable estimates with little worry about endogeneity bias if the economic variable of interest is the interaction term".

Bushman et al. (2004) also employ OLS to test the effect of various interaction terms on their dependent variable, with Earnings Timeliness (the likely endogenous variable) as one variable in the interaction terms. They argue that when instrumental variables explain only small portion of Earnings Timeliness, the use of instrumental variables would throw out major portion of the variation the timeliness and this may reduce the validity of the regression results.

Hypothesis 5 states that ownership by the largest shareholder/cash-flow rights weakens the

Table 8. OLS Results of Board Size as the Dependent Variable with Firm Performance and Ownership Structure as Interaction Variables

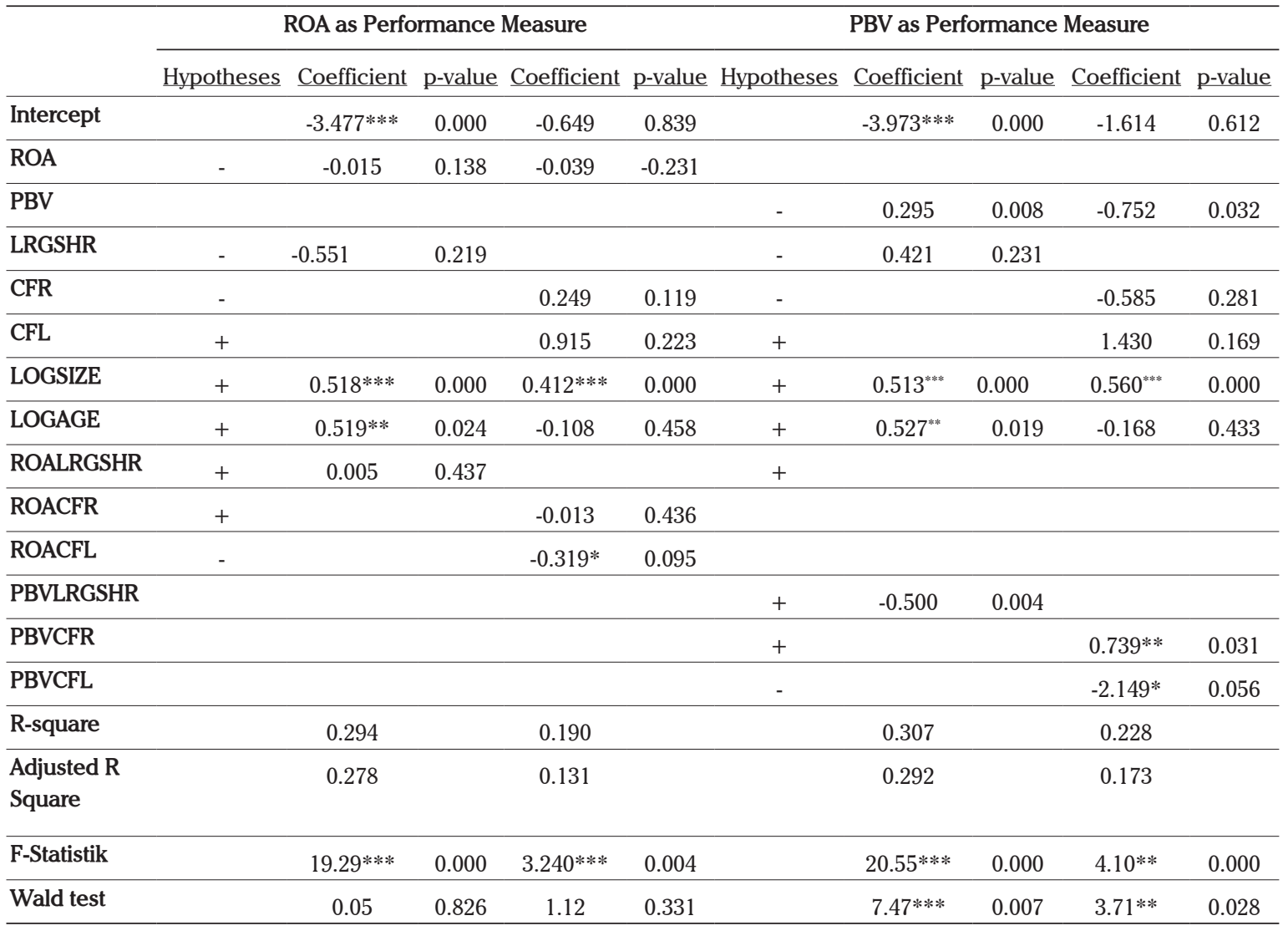

Note: $\mathrm{ROA}=$ Return On Assets, $\mathrm{PBV}=($ Stock$)$ Price to Book Value of equity per share, $\mathrm{BOC}=$ size of BOC, INDEP $=$ proportion of independent commissioners, LRGSHR = percentage ownership of the largest shareholders, CFR = Cash-Flow Rights, CFL $=$ Cash-Flow Rights - Control Rights, INST $=$ dummy variable, coded as 1 for institutional ownership greater than $20 \%$ and zero otherwise, DEBT = debt over total assets, LOGSIZE = log(firm) size, LOGAGE = log(firm age).

*significant at 10 percent level; **significant at 5 percent level; ***significant at 1 percent level 
negative effect of firm performance on board size. The hypothesis is tested with two measures of performance (ROA and PBV) and two measures of ownership concentration (the share ownership of the largest shareholder (LRGSHR) and the CashFlow Rights of the largest shareholder (CFR)). Thus, there are four OLS models to test the hypothesis. Hypothesis 6 states that the negative effect of firm performance on board size is strengthened for firms with high-risk of expropriation (i.e., greater divergence between control and cash-flow rights). Before we test the hypotheses 5 and 6, we conduct Wald tests on the inclusion of interaction variable(s). In Table 8, when performance measure is PBV, the Wald test indicates that the interactions variables significantly improve the model fit. However, when performance measure is ROA, the interaction variables do not improve the model fit.

The results of testing hypothesis 5 are as follow. Table 8 show that the coefficient of interaction between the PBV and CFR (PBV*CFR) is positive, which is in accordance with Hypothesis 5. Thus, we find that ownership concentration weakens the negative effect of firm performance on board size when firm performance is measured by PBV and ownership concentration is measured by CFR. The level of CFR measures the alignment of interest between controlling shareholders and noncontrolling shareholders. Thus, when the alignment interest is high, the risk expropriation is low. Under this condition, the demand to have larger board size to overcome poor performance is reduced.

The results for testing Hypothesis 6 are as follow. Table 8 documents that the coefficients of interaction between PBV and CFL (PBV*CFL) are significant at $90 \%$ confidence level. Thus, there is weak evidence that for firms with high-risk of expropriation, firm performance and board size is strongly negatively related.

Based on the results in Table 4 and 8, our empirical tests find that Cash Flow Leverage does not have a direct effect on the size of the board; however, it has marginal indirect effect on board size by strengthening the effect of firm performance on board size. Higher level of CFL indicates higher risk of expropriation of non-controlling shareholders. Thus, when the incentive to expropriate is high, a larger board is needed to improve those poorly performing firms.

Based on OLS result, our result show that given the weak legal efficacy in Indonesia, in firms with a high entrenchment effect (i.e., a high divergence between control and cash-flow rights), apparently the incentive to strengthen the role of the $\mathrm{BOC}$ to provide oversight (through having a larger board) in poorly performing firms is stronger than in other firms.

\section{Further Tests}

Since the period of the study is two year, there can be serial correlation within the panel data. The existence of severe serial correlation increases the possibility to wrongly reject the null hypothesis. To examine if the test results are sensitive to the existence of serial correlation, the study conducts the 2 SLSfixed effect instrumental variable (IV) regressions and random effect IV regressions. The results can be seen in Table 9. For the sake of brevity, the results shown are the results of the effect interaction between ownership structure and firm performance on board size.

In general the results are qualitatively similar with the regression results in Table 8 . The coefficients of interaction between cash-flow rights and firm performance (ROA and PBV) are significantly positive, supporting the hypothesis that higher cash-flow rights tend to reduce the negative effect of performance on board size. When ownership share of controlling shareholders is measured by share of direct ownership the coefficients are not significant. The plausible explanation is that the variable is measured with error since it ignores the indirect ownership of the controlling shareholders. This measurement error tends to bias the results against supporting the hypothesis. 
Table 9. The Effects of Interaction between Performance and Ownership Structure on Board Size based on the Results of Fixed-effects (within) IV regression and G2SLS Random-Effects IV regressions

\begin{tabular}{|c|c|c|c|c|c|}
\hline \multirow{3}{*}{ Interaction Variables } & \multirow{3}{*}{ Expected Sign } & \multicolumn{4}{|c|}{ Dependent Variable: Board Size } \\
\hline & & \multicolumn{2}{|c|}{$\begin{array}{c}\text { Fixed-effects (within) IV } \\
\text { Regression }\end{array}$} & \multicolumn{2}{|c|}{$\begin{array}{l}\text { G2SLS random-effects IV } \\
\text { regression }\end{array}$} \\
\hline & & Coefficient & p-value & Coefficient & p-value \\
\hline ROALRGSHR & + & -0.016 & 0.050 & -0.016 & 0.296 \\
\hline ROACFR & + & $0.165^{* *}$ & 0.046 & $0.211 * * *$ & 0.015 \\
\hline ROACFL & - & 0.187 & 0.08 & 0.217 & 0.062 \\
\hline PBVLRGSHR & + & -0.016 & 0.050 & -3.435 & 0.001 \\
\hline PBVCFR & + & $0.478^{*}$ & 0.073 & 0.418 & 0.114 \\
\hline PBVCFL & - & $-2.144 * * *$ & 0.005 & 0.313 & 0.297 \\
\hline
\end{tabular}

Note: $\mathrm{ROA}=$ Return On Assets, $\mathrm{PBV}=$ Stock Price/Book Value of Equity, LRGSHR = \% ownership by the largest shareholder, CFR $=$ Cash-Flow Rights, CFL $=$ Cash-Flow Rights - Control Rights,

*significant at 10 percent level; **significant at 5 percent level; ${ }^{* * *}$ significant at 1 percent level

With regard to the moderating effect of cashflow leverage (CFL) on the relation between performance and board size, only the interaction between CFL and PBV under the fixed effect model that is significantly negative while if the performance measure is ROA or the regression is based on the random effect model the interaction coefficients are not significant. Thus, there is weak evidence that higher cash-flow leverage strengthens the negative effect of performance on board size.

\section{MANAGERIAL IMPLICATIONS}

The managerial implications of the results of our study are as follow. The inverted $\mathrm{U}$ shape relation between board size and firm performance implies that when determining the size of the board of commissioners, shareholders need to ensure that to maximize performance, the size of the $\mathrm{BOC}$ is not too small or too big. When the size of BOC is too small, the oversight and advisory roles of BOC are not optimal due to limited resources. However, when the size of BOC is too big, coordination and communication among board members become more difficult and this may hamper performance.

The finding of the study that performance negatively affects size of board implies that poorly perfoming firms need larger BOC size so the BOC will be able to provide direction to improve performance. This is especially important for firms with high risk of expropriation by controling shareholders. On the other hand, for firms whose controlling shareholders have high ownership, increasing board size for improving performance is not really needed since controlling shareholders have genuine incentive to enhance performance.

\section{Limitation and future research}

The study has several limitations as explained below: 1) As explained above, our measures of a firm performance (ROA and PBV) have some measurement errors due to the application of accounting conservatism and/or the stock price not reflecting the intrinsic value of the company. We suggest that future studies refine this measurement by removing the impact of conservatism and by limiting the samples to only those firms whose stocks are liquid/frequently traded on the stock exchange; 2) Since the period of our study (20072008) covers the period of global financial crisis which may have impact on the results of our study, we suggest that future studies replicate this study with the use of different period from our study. 3) Samples of the study are manufacturing firms. To improve the external validity of the study, future studies need to include firms from various sectors 
as the samples of the study. 4) One measure of ownership concentration (i.e., direct ownership by the largest shareholder) contains errors since it ignores any indirect ownership through pyramid ownership structures. The use of cash-flow rights mitigates this limitation; however, the number of observations becomes relatively small. Therefore, we suggest that future studies collect more data on cash-flow rights and the cash-flow leverage of listed companies and use the data to replicate our study. 5) We employ two stages least squares since we consider only firm performance and board size as endogeneous variables. It is possible that other variables (e.g., ownership structure variable) are endogenously determined. Therefore, future studies need to consider this possibility and employ the suitable empirical model to test the simultaneous relations. 6) We use samples only from one country (i.e., Indonesia) that has weak legal environment. Thus the results of the study may not apply to other countries with different legal environment. Therefore, we suggest that future studies shall use firms from cross-countries to examine if legal environment influences the inter-relation between different measures of ownership structure and board size.

\section{CONCLUSION}

The purpose of this study is to investigate: Firstly, the two-way causality between firms performance and the size of BOC; secondly, the non-linear effect of board size on the firms performance; thirdly, the direct and moderating effects of the ownership structure on the influence of firm performance on board size.

Using the ROA as a measure of firm performance, we find that there is a simultaneous relationship between firm performance and the size of BOC: the size of the board has an inverted $U$-shaped effect on firm performance while firms performance has a negative influence on board size. We find that the size of the board of commissioners increases firm performance up to certain level, but very large board reduces firm performance. Our findings are consistent with studies that find non-linear effect of board size on performance and negative effect of performance on board size under the single board structure. Thus, this causal relations between board size and performance occur regardless the structure of the board (single or dual board).

We find that different measures of ownership structure do not have a direct influence on board size in accordance with the hypothesis. However, we find marginal evidences that ownership structure has a moderating effect on the impact of firm performance on board size. We document that as ownership right increases, the negative effect of performance on board size dissipates. On the other hand, as the difference between control and ownership right increases, the negative effect of performance on board size marginally strengthens. Thus, our study contributes to the literature by finding that the negative influence of firm performance and board primarily occurs on firms that are subject to high incentive expropriation by controlling shareholders. Further, we show that for firms whose controlling shareholders' interests are aligned with the interest of other shareholders, there is no need to increase board size in respond to poor performance.

\section{Implication to Policy Makers}

The implications of the study are as follows: Currently a large number of listed companies in Indonesia currently have only two or three commissioners, while many of these companies either have a high risk of expropriation by their controlling shareholders or low ownership by the larger shareholders. These companies tend to perform poorly and are avoided by investors. Therefore, to attract the general public to invest money in the capital market, the capital market regulator needs to develop a policy that encourages listed companies to select boards of a suitable size that are in line with their characteristics. For example, companies are mandated to disclose their rationale for choosing the size of their $\mathrm{BOC}$, and how each commissioner is performing his/her duties. 
Since firm size positively affect board size, the regulator may also implement a rule that mandates the minimum size of board varies depending on firm size. The existing rule requires minimum number of two commissioners regardless firm size.

The study also shows that poor performance does not necessarily result in the increase in board size. When the interests of controlling shareholders are aligned with non-controlling shareholders, they have incentive to maximize firm value and this does not require an increase in board size. The policy implication is that the capital market regulator needs to pay more attention to poorly performing firms with high risk of expropriation, for example, by encouraging these firms to restructure the $\mathrm{BOC}$ that is in line with maximizing firm value.

\section{REFERENCES}

Arosa, B., Iturallde, T., Maseda, A. (2013). The board's structure and firm performance in SMEs: Evidence from Spain. Investigaciones Europeas de Dirreccion y Economia de la Empresa 19, 127-135.

Baysinger, B.D., Butler, H.D. (1985). Corporate governance and the board of directors: Performance effects of changes in a board's composition. Journal of Law, Economics, and Organization, 1, 101 - 124.

Belkhir, M. (2009). Board of Directors' Size and Performance in the Banking Industry. International Journal of Managerial Finance 5(2), 201-221.

Bhagat, S., Black, B. (2001). Board independence and long-term form performance. Journal of Corporation Law, 27.

Bjuggren, P., Eklund, J.E., Wiberg, D. (2007). Institutional Owners and Return on Investments, Centre of Excellence for Science and Innovation Studies (CESIS) Electronic Working Paper Series, Paper no. 96.

Brown, L. D., Caylor, M.L. (2006). Corporate Governance and Firm Valuation. Journal of Accounting and Public Policy 25, 409-434.

Brown, P., Beekes, W., Verhoeven, P., 2011. Corporate governance, accounting and finance: A review. Account. Financ. 51, 96-172.

Bun, M.J.G., Harrison, T.D. (2014). OLS and IV estimation of regression models including endogenous interaction terms, retrieved March 3, 2017 from https:/www.maxwell.syr.edu/uploadedFiles/cpr/events/cpr_camp_econometrics/ papers2014/bun_harrison.pdf

Bushman, R., Chen, Q., Engel, E., Smith, A., 2004, Financial accounting information, organizational complexity and corporate governance systems, Journal of Accounting and Economics 37, 167-201.

Carney, M., Gedajlovic, E. (2001). Corporate governance and firm capabilities: A comparison of managerial, alliance, and personal capitalisms, Asia Pacific Journal of Management 18(3), 335-354

Chaganti, R., Damanpour, F.,(1991) Institutional ownership, capital structure, and firm performance. Strategic Management Journal 12, 479-491.

Charfeddine, L., Elmarzougui, A. (2010). Institutional ownership and firm performance. The IUP Journal of Behavioral Finance 7(4), 35-46.

Chen, C. H., and B. Al-Naijar. (2012). The determinants of board size and independence: Evidence from China, International Business Review 21(5): 831-846.

Guest, P. M. (2008). The determinants of board size and composition: Evidence from the UK, Journal of Corporate Finance 14(1): 51-72.

Cheng, S. (2008). Board size and the variability of corporate performance. Journal of Financial Economics 87, 157-176.

Cho, M. H. (1998). Ownership structure, investment, and the corporate value: An empirical analysis. Journal of Financial Economics,47, 103-121.

Claessens, S., Djankov, S. Lang, L.H.P. (2000). The separation of ownership and control in East Asian corporations. Journal of Financial Economics 58(1-2), 81-112. 
Claessens, S., J.H.P. Fan and L.H.P. Lang. (2002a). The Benefits and costs of group affiliation : Evidence from East Asia, Working Paper, University of Amsterdam, Hong Kong University of Science \& Technology, and the Chinese University of Hong Kong.

Claessens, S., S. Djankov, J.P.H. Fan, and L.H.P Lang (2002b). Disentangling the incentive and entrenchment effects of large shareholdings, The Journal of Finance, 57 (6): 2741-277.

Coles, J., Daniel, N., Naveen, L., 2008. Boards: Does one size fit all? Journal of Financial Economics 87, 329-356.

Coles, J. L., Lemmon, M. L., Meschke, J. F. (2012). Structural models and endogeneity in corporate finance: The link between managerial ownership and corporate performance, Journal of Financial Economics 103, 149-168.

Conheady, B., P. Mckllkenny, K. K. Opong, I. Pignatel. (2015). Board effectiveness and board performance of Canadian listed firms, The British Accounting Review 47: 209-303.

Conyon, M. J. and Peck, S. I. (1998) Board size and corporate performance: Evidence from European countries, European Journal of Finance (4), 291-304.

Cornett, M. M., Marcus, A. J., Saunders, A., Tehranian, H. (2007). The impact of institutional ownership on corporate operating performance, Journal of Banking and Finance 31, 1771- 1794.

Cornett, M. M., Marcus, A. J., Tehranian, H. (2008). Corporate governance and pay-for-performance: The impact of earnings management, Journal of Financial Economics 87, 357-373.

Croci, E., Gonenc, H., Ozkan, N. (2012). CEO compensation, family control, and institutional investors in Continental Europe. Journal of Banking \& Finance 36(12), 3318-3335.

Dahlquist, M., Robertsson, G. (2001). Direct foreign ownership, institutional investors, and firm characteristics, Journal of Financial Economics 59, 413-440.

Daily, C., Dalton, D., Rajagopalan, N. (2003). Governance through ownership: Centuries of practice, decades of research", Academy of Management Journal 46(2), 151-158.

Dalton, D. R., Daily, C.M., Johnson, J.L., Ellstrand, A.E. (1999). Number of directors and Financial performance: A meta analysis, Academy of Management Journal 42(6), 674-686.

de Andres, P., Azofra, V. and Lopez, F. (2005). Corporate boards in OECD countries: Size, composition, functioning and effectiveness, Corporate Governance: An International Review 13(2), 197-210.

Demsetz, H., Villalonga, B. (2001). Ownership structure and corporate performance. Journal of Corporate Finance 7, 209-233.

Denis, D. J., Sarin, A. 1999. Ownership and board structure in publicly traded corporations. Journal of Financial Economics 52, $187-223$.

Diyanti, V., Utama, S., Rossieta, H., Veronica NPS, S. (2010). The effects of ultimate controlling ownership on the related party transactions and earnings management, Working Paper, Universitas Indonesia.

Duggal, R., Millar, J.A. (1999). Institutional Ownership and firm performance: The case of bidder returns. Journal of Corporate Finance 5, 103-117.

Eisenberg, T., Sundgren, S., Wells, M. (1998). Larger board size and decreasing firm value in small firm. Journal of Financial Economics 48, 35-54.

Eliyanora. (2008). Pengaruh Ukuran dewan, komisaris independen, dan kepemilikan institusional terhadap non performing loan. Thesis, Fakultas Ekonomi Universitas Indonesia.

Elloumi, Gueyi, (2001). Financial Distress and Corporate Governance: An Empirical Analysis, Corporate Governance 1(1), $15-23$.

Fama, E., Jensen, M., (1983). Separation of ownership and control. Journal of Law and Economics 26, 301 - 325.

Gillan, S. L., Starks, L.T. (2000). Corporate governance proposals and shareholder activism: The role of institutional investors, Journal of Financial Economics 57, 275- 305.

Gilson, S. (1990). Bankruptcy, boards, banks, and blockholders, Journal of Financial Economics 26, 355-387.

Giri. (2008). Pengaruh prosentase komisaris independen, kepemilikan manajerial, kepemilikan institusi dan konsentrasi kepemilikan terhadap kinerja dan nilai perusahaan pada perusahaan di Bursa Efek Indonesia. Thesis. Fakultas Ekonomi Universitas Indonesia.

Goodstein, J., Gautam, K., Boeker, W. (1994). The effect of board size and diversity on strategic change. Strategic Management Journal 15, 241-250.

Hampel, R. (1998). Committee on Corporate Governance: Final Report', Gee; London.

Hartzell, J. C., Starks, L.T. 2003, Institutional investors and executive compensation, Journal of Finance 58, 2351-2374.

Hermalin, B., Weisbach, M. (1988). Endogenously chosen boards of directors and their monitoring of the CEO. American Economic Review 88, 96 - 118.

Hermalin, B., Weishbach, M. (1991). The effect of board composition and direct incentives om firm performance, Financial Management, 1001-112. 
Hermawan, A.A. (2009). Pengaruh Efektifitas Dewan Komisaris dan Komite Audit, Kepemilikan oleh Keluarga, dan Peran Monitoring Bank terhadap Kandungan Informasi Laba. Disertation, Fakultas Indonesia Universitas Indonesia.

Higgs, D. (2003). Review of the Role and Effectiveness of Non-executive Directors, The Department of Trade and Industry; London.

Himmelberg, C., Hubbard, R., Palia, D. (1999). Understanding the determinants of managerial ownership and the link between ownership and performance. Journal of Financial Economics 53, 353-384.

Jensen, M. C., Meckling, W. (1976). Theory of the Firm: Managerial behavior, agency cost, and ownership structure. Journal of Financial Economics 305-360.

Jensen, M.C. (1993). The modern industrial revolution, exit, and the failure of internal control systems. The Journal of Finance $48,831-880$

Johnson, S., Boone, P., Breach, A., Friedman, E. (2000). Corporate governance in the Asian financial crisis. Journal of Financial Economics 58, 141-186.

Kieso, D.E., Weygandt, J.J., Warfield, T.D. (2008). Intermediate Accounting, John Wiley and Sons Inc.

Klein, A. (1998). Firm performance and board committee structure. Journal of Law \& Economics, 41, $275-303$.

Lehmann, E.,Weigand, J. (2000). Does the governed corporation perform better? Governance structures and corporate performance in Germany, European Finance Review 4(2), 157-195.

La Porta, R., Lopez-de-Silanes, F., Shleifer, A. (1999). Corporate ownership around the world. The Journal of Finance 54(2), 471-517.

Leng, A.C.A. (2004). The impact of corporate governance practices on firms' financial performance: Evidence from Malaysian companies, ASEAN Economic Bulletin Vol. 21, No. 3, pp. 308-318.

Linck, J., Netter, J., Yang, T. (2008). The determinants of board structure. Journal of Financial Economics 87(2), 308-328.

Lipton, M., Lorch, J. W. (1992). A modest proposal for improved corporate governance. The Business Lawyer 48, 59-77

Lowenstein, L. (1991). Why managers should (and should not) have respect for their shareholders. Journal of Corporation Law 17, 1-27.

Mak, Y.T., Li, Y. (2001). Determinants of corporate ownership and board structure: Evidence from Singapore, Journal of Corporate Finance 7(3), 235-256.

Market valuation: An empirical analysis, Journal of Financial Economics, 20, 293-315.

McConnell, J.J., Servaes, H. (1990). Additional evidence on equity ownership and corporate value. Journal of Financial Economics 27, $595-612$

Melati, I., Rijken, H.A., Utama, S. (2010). Ownership structure and firm performance: Additional evidence from Indonesia, Working Paper.

Morck, R., Shleifer, A.,Vishny, R. W. (1988). Management ownership and market valuation: An empirical analysis, Journal of Financial Economics 20, 293-315.

Mishra, D. R. (2011). Multiple large shareholders and corporate risk taking: Evidence from East Asia, Corporate Governance International Review 19(6): 507-528.

Muniandy, B., Hillier, J. (2015). Board independence, investment opportunity set, and performance of South African firms, Pacific-Basin Finance Journal xxx, 1-17.

Munisi, G., N. Hermes, and T. Randoy. (2014). Corporate boards and ownership structure: Evidence from South-Saharan American, Internatinal Business Review 23: 785-796

O'Connell, V., Cramer, N. (2010). The relationship between firm performance and board characteristics in Ireland, European Management Journal 28, 387- 399.

Peng, M.W., C.C. Mutlu, S. Sauerwald, K.Y. Au, and D. Y. L. Wang. (2015). Board interlocks and corporate performance among firms listed abroad, Journal of Management History 21 (2): 257-282.

Puspita, Lukviarman, (2007). Board governance dan kinerja Perusahaan (studi terhadap perbankan go publik di BEJ), The 1st Accounting Conference FEUI, Depok.

Raheja, C. (2005). Determinants of board size and composition: A theory of corporate boards. Journal of Corporate Finance $3,113-139$

Rosenstein, S., Wyatt, J.G. (1990). Outside Directors, Board Independence, and Shareholder Wealth, Journal of Financial Economics, 26, 175-192.

Ross, S.A.,Westerfield, R.W., Jordan, B.D. (2009). Modern Financial Management. McGraw-Hill. Eight Edition.

Seifert, B., Gonenc, H., Wright, J. (2005). The international evidence on performance and equity ownership by insiders, blockholders, and institutions, J. of Multi. Fin. Manag. 15, 171-191.

Shleifer, A., and M. W. Vishny. (1986). Large shareholders and corporate control. Journal of Political Economy 94: 461-488.

Shleifer, A., Vishny, R. W. (1999). A survey of corportae governance. Journal of Finance 52 (2), 737-783. 
Sing, S.S.G.H.B.D. (2015). Ownership concentration, board characteristics and firm performance, Management Decision 53(5), $911-931$

Siregar, S. V., Utama, S. (2008). Type of earning management and the effect of ownership structure, firm size, and corporate governance practice: Evidence from Indonesia. The International Journal of Accounting 43, 1-27.

Stiles, P., Taylor, B. (2001). Boards at work: how directors view their roles and responsiblities. Oxford: Oxford University Press.

Utama, C. A. (2012). Company disclosure in Indonesia: Corporate governance practice, ownership structure, and total assets, Asian Journal of Business and Accounting 5(1): 1-25.

Van den Berghe, L.A.A, Levrau, A. (2004). Evaluating board of directors: What constitutes of board a good of corporate board? Corporate Governance of International Review 12, 461-478.

Wardhani, R. (2006). Mekanisme corporate governance dalam perusahaan yang mengalami permasalahan keuangan (financially distressed firms). Simposium Nasional Akuntansi 9. Padang.

Yermack, D. (1996). Higher market valuation of companies with a small board of directors. Journal of Financial Economics $40,185-211$.

Zefanya. (2008). Analisis pengaruh ukuran dewan, komisaris independen, dan kepemilikan manajerial terhadap NPM, ROA dan ROE sebagai kinerja keuangan perusahaan, Thesis, Fakultas Ekonomi, Universitas Indonesia

Zuna, S. U. (2009). Komisaris, CEO, Tipe Kepemilikan Saham Pengendali dan Risk Taking pada Industri Perbankan di Indonesia Periode 2004-2008, Thesis, Fakultas Ekonomi Universitas Indonesia. 